\title{
The general partnership in German law
}

\author{
by Frank Wooldridge
}

\section{INTRODUCTORY REMARKS}

The German OHG (offene Handelgesellschaft) corresponds to the French société en nom collectif. Like the latter entity, certain of its features resemble those of business entities in use in North Italy in the later Middle Ages and the Renaissance. Provision for such a partnership was made in the Allgemeines Deutschen Handelsgesezbuch of 1850 and the German Commercial Code of 1900. It is now regulated by paragraphs 105-16 of the German Commercial Code: the rules governing it underwent considerable revision in 1998. Certain of the provisions of the Civil Code (Bürgerliches Gesetzbuch) are also applicable to it. The account of this entity in pages 68-100 of the sixth edition of Kübler and Assmann's work Gesellschaftsrecht has been of considerable assistance to the writer.

There are a considerable number of ordinary or general commercial partnerships in Germany, but this entity does not appear as popular as the private limited liability company $(\mathrm{GmbH})$ at present. This is probably because many business people currently fear the possible consequences of unlimited liability. However much of the law relating to the commercial partnership is applicable to the limited partnership (KG or Kommanditgesellschaft) which is in frequent use in that country, as is the hybrid entity the $G m b H$ \& Co $K G$, in which a private company is a member of a limited partnership and carries out business transactions on its behalf; it is usually the limited partner. The latter entities are of some importance in Germany and are often of a considerable size. Certain of the laws relating to the general commercial partnership are applicable to these entities, as it also is in the European economic interest grouping EWIG or Europäisches Wirtschaftsliches Interessenvereinigung. Although the civil partnership ( $B G B$ Gesellschaft) is principally regulated by the German Civil Code, certain of the rules governing commercial partnership have been applied to it by the German court.

\section{DEFINITION AND SIGNIFICANT CHARACTERISTICS}

According to paragraph 105(1) of the German Commercial Code, a partnership formed for the purpose of carrying on a commercial enterprise under a common name (Firma) is a general commercial partnership provided creditors of the partnership. By paragraph 1(2) of the Code a commercial enterprise consists of the activities of a commercial undertaking which according to its nature and circumstances has to be carried on in a commercially oriented business establishment. The common pursuit of such an activity gives rise to a commercial partnership. If the undertaking is so small and simple that it does not require any commercially oriented business establishment, the common pursuit of the activity only gives rise to a civil law partnership (Gesellschaft des bürgerlichen Rechts). However, if the undertaking is registered in the Commercial Register, it follows from paragraphs 2 and 105(2) of the Code that it is treated as a commercial partnership.

The commercial partnership is treated as a personalistic entity, having a limited number of members, rather than a corporate body having a large number of members such as a Verein (association), cooperative society, or a capitalistic company such as a public company. Its membership is not restricted to natural persons. It has the capacity to enter into legal transactions, or to acquire property and to sue and be sued under its own name. It is not however treated as having legal personality, but rather as a community of joint owners (Gesamthandsgemeinschaft). This treatment does not prevent it from being converted into a capital company without any need to undergo liquidation and the formation of a new company.

According to paragraph 123(1) of the Commercial Code the commercial partnership operates with effect against third parties once it is registered in the Commercial Register. However, according to paragraph 123(2), if it begins to transact business before such registration, its effectiveness against third parties begins from the commencement of such business, provided that at the relevant time it is a commercial enterprise. Paragraph 123(3) of the Code provides that any agreement which provides that a partnership shall commence at a later date (than registration) shall have no effect as against third parties.

\section{THE LEGAL RELATIONSHIP AND POWERS OF THE PARTNERS}

According to paragraph 109 of the Commercial Code, this is regulated initially by the partnership agreement; the provisions of paragraphs $110-122$ are applicable only to 
the extent that the agreement does not otherwise provide. It is questionable how far the agreement may deviate from such provisions without infringing mandatory legal concepts. The partners are required to make their contributions, and to participate in the management of the business of the commercial partnership in accordance with paragraph 114(1) of the Code. They are bound by a duty of good faith to one another and the partnership which is not regulated in the Code. Paragraph 112(1) thereof provides for a prohibition on competition. It stipulates that partners may not, without the consent of the other partners, conduct business in the partnership's field of activities or participate as a general partner in another similar commercial partnership. Such participation is apparently permitted if the partner is excluded from involvement in the management and representation of the other partnership.

Paragraph 114(1) provides that all the partners are authorised and obliged to manage the partnership business. However, paragraph 114(2) of the Code provides that where the management of the business is transferred to one or more partners by the partnership agreement, the remaining partners may be excluded from management. Paragraph 118(1) provides that where the partner is excluded from management he must remain informed as to the partnership's affairs, be able to examine the books and records of the partnership, and prepare a balance sheet and annual financial statements thereform. According to paragraph 118(2) any agreement limiting or excluding such rights of inspection shall not prevent the assertion thereof if there is reason to suspect dishonest management.

According to paragraph 115(1) of the Code, where all or several of the partners are entrusted with management, each one of them is authorised to act alone; however, in the event that another managing partner objects to such an action, it shall not be taken. Paragraph 115(2) provides that if the partnership agreement stipulates that the managing partners shall only act jointly, every business transaction shall require the consent of all the managing partners, unless there is a risk of delay.

By paragraph 116(1) of the Code, management authority extends to all acts connected with the ordinary operation of the commercial partnership. Transactions which exceed this limitation are required by paragraph 116(2) to be authorised by a resolution of all the partners. By paragraph 116(3), the appointment of a Prokurist shall require the consent of all managing partners, unless there is a risk in delay. Revocation of the Prokura may be effected by any of the partners authorised to grant or participate in the granting of the Prokura. A Prokura is a power of full commercial representation given to a person called the Prokurist.

Management authority may, according to paragraph 117, be revoked with respect to one partner for cause by means of a judicial decision on the application of the other partners. Without limiting the generality of the latter provision, such cause includes gross violation of duty, or inability to properly manage the business. As the provisions of paragraph 117 are dispositive, and not mandatory, they may be modified by the provisions of the partnership contract. Where paragraph 117 is applicable the application to the court must be made by all the other partners.

According to paragraph 119(1) resolutions passed by the partners require the consent of all the partners entitled to participate in them. By paragraph 119(2) of the Code, if a majority vote is required by the partnership agreement, this majority is calculated, in cases of doubt, on the basis of the number of partners. The relevant resolution does not require a specific form or procedure; it may be passed by the exchange of correspondence, circulation thereof, or by means of telephonic media. If a resolution is likely to have prejudicial consequences for a partner if it is passed, for example by deciding that he shall lose his managerial or representative power, the relevant partner is excluded from voting on it. The power contained in paragraph 119(2) of the Commercial Code permitting resolutions to be passed by a majority vote is not intended to be understood as giving power to the partners to alter the partnership agreement by such a vote, unless power to do so is expressly given therein. In the latter event such power will not be treated as exercisable where the agreement was intended to provide for the increase of a partner's contribution, unless the agreement contains a rule excluding the provisions of paragraph 707 of the Civil Code, which provides that the members of a personalistic company are not required to increase their promised contributions thereto without their consent. If no such exclusionary rule was contained in the partnership agreement, its amendment would have to take place by a unanimous vote. Any of the partners is empowered to request the competent court to annul a resolution passed by the partners.

\section{PARTNERSHIP PROPERTY AND ITS TREATMENT}

Every commercial (or general) partnership makes provision for partnership property, which is in the collective ownership of the partners. The partnership is designed to make profits, although it may in fact incur losses. Problems arise as to how such profits and losses shall be apportioned among the partners. They also occur in relation to the circumstances and extent that the individual partners may make use of the partnership resources for their own purposes. Furthermore, questions arise as to how the remaining property of the partnership shall be apportioned among the partners upon its liquidation, and what shall be given to a partner who is excluded from the partnership or who voluntarily withdraws from it.

The above questions are dealt with in paragraphs 120122 and paragraphs 155 of the Commercial Code. The 
former three paragraphs may be excluded by the commercial partnership agreement. Paragraphs 121(1) and 122(2) use the concept of the Kapitalanteil (share in the capital) which is regrettably undefined. It must not be confused with two other concepts, the Vermögensanteil and the Gesellschaftsanteil. The Vermögensanteil consists of the value of the partner's share in the joint assets of the partnership. This value will not be the same as that indicated by the Kapitalanteil if the balance sheet figures used in determining are not regularly adjusted in accordance with paragraph 120(1) of the Commercial Code, or if the partnership has secret reserves. The Gesellschaftsanteil indicates the totality of the rights enjoyed by a partner as the result of this membership of the commercial partnership. It thus includes his participation in the assets as well as his rights and duties and powers of participating in decisions. Unless the partnership agreement provides otherwise, the Gesellschaftsanteil is not transferable.

The Kapitalanteil of a partner is determined every year according to paragraph 120(2) of the Code. The profits attributable to the partner are credited to his share of the capital, whilst the losses borne by him and the money withdrawn from his share in the capital during the business year are deducted therefrom. It is possible for the capital share of a shareholder to have a negative value. It should be remembered that paragraphs 120-2 of the Commercial Code do not have to be adopted by the partnership.

The apportionment of profits and losses is governed by paragraph 121. Each partner is initially entitled to a dividend of 4 per cent of his share in the capital. Any excess of dividend over the preferential 4 per cent is also distributed to the partners in addition to the latter dividend. If it is impossible to pay the preferential dividend, the profit share is calculated at the lower rate. According to paragraph 122, each partner is authorised to withdraw funds from the partnership accounts up to an amount equal to four per cent of his share in the capital determined in respect of the last business year. To the extent that it does not cause obvious harm to the partnership, each partner may require the payment of any profit share for the preceding business year which exceeds the prescribed amount. Paragraph 155(1) of the Code provides that partnership properly remaining after the satisfaction of debts in a liquidation is to be distributed by the liquidators among the partners in proportion to their shares in the capital as shown by the closing balance sheet.

The rules contained in paragraphs 121(1), 122(1) and 155(1) often prove to be unsatisfactory and are frequently replaced by different provisions in the partnership agreement.

\section{LEGAL RELATIONSHIPS WITH THIRD PARTIES}

Such relationships are principally regulated by paragraphs 123-130 of the Commercial Code, which are essentially mandatory in nature. Among the most important of these provisions are those of paragraphs 128 130 , which deal with the personal liability of partners and the defences available to them. Other important provisions in these paragraphs deal with the position of the partnership and its representation in legal transactions. Although the partnership is not treated as having legal personality, it operates as a separate entity under its own name, and can be entered in the Land Registry under its own name. It is treated as capable of being responsible for the wrongful acts of a partner done in the course of carrying out his duties.

According to paragraph 124(1) of the Code, the general commercial partnership can acquire rights and incur obligations, acquire title and other rights in real property, and sue and be sued under its business name. Paragraph 124(2) provides that a legally enforceable claim of debt against the partnership is required for execution against its property. Detailed rules governing the representation of the partnership are contained in paragraph 125 of the Commercial Code. Paragraph 125(1) provides that each partner is empowered to represent the partnership unless he has been excluded from representation by the partnership agreement. It is not possible to exclude all the partners from such representation. According to paragraph 125(2) the partnership agreement may provide that all of several partners shall represent the partnership jointly. It also provides that the partners authorised to represent the partnership jointly may empower individual partners to carry out specific transactions or specific types of transactions. Furthermore, it stipulates that if a legal declaration has to be made to the partnership, it may be made to one of the partners authorised to take part in the representation. Finally, paragraph 125(3) provides that the partnership agreement shall provide that, where the partners do not act jointly, they shall be empowered to represent the partnership only when acting with a Prokurist.

According to paragraph 106(2) No 4 of the Commercial Code, the application for registration of a commercial partnership must include particulars of the power of representation of the partners. Paragraph 107 of the Code provides that particulars must be given of any alteration in the powers of representation of a partner. According to paragraph 127, the power of representation may be removed from a partner by the court on the application of the other partners when an important ground for such removal exists; such a ground includes the gross violation of duties or incapacity to manage the business adequately.

It follows from paragraph 126(1) of the Code that the power of representation of the partners extends to all judicial and non-judicial proceedings and transactions, including the transfer and encumbrance of real property and the grant and revocation of a Prokura. Paragraph 126(2) provides that a restriction on the power of representation shall be ineffective in relation to third parties: this rule applies in particular to a restriction that 
representation extends only to particular transactions or kinds of transactions or the power may only be exercised under certain circumstances, for a specific period of time or at a certain location. It seems however that when a third party had dishonestly colluded with a partner who had exceeded his power of representation or who should have known of his lack of such power if he had exercised the necessary degree of care, may not be protected by paragraph 126(2) (see Kübler and Assmann, op cit, p 83).

\section{LIABILITY FOR OBLIGATIONS}

According to paragraph 124(1) of the Code, a general commercial partnership may acquire rights and incur obligations, sue or be sued under its name (Firma) and be placed in insolvency. By paragraph 124(2) a legally enforceable title to a debt (Schuldtitel) is necessary for execution to take place against the property of the partnership. The ambit of the obligations of a commercial or limited partnership has been extended by the decisions of the courts governing, and the academic comment on, paragraph 31 of the Civil Code, which concerns the liability of an association having legal personality (Rechsfähige Verein) for the acts of its organs. It is now recognised that if a partner causes damage to a third party whiles pursuing his activities on behalf of the commercial partnership, the partnership is liable for such damage. The personal liability of a partner towards the partnership is governed by paragraph 128 of the Code, which provides that the partners are jointly and severally liable in respect of the obligations of the partnership towards creditors. Any agreement to the contrary has no effect against creditors. The liability has to be met not only out of the property of the partnership, but also out of the property of each individual partner.

A partner is directly liable to the creditor of the partnership, and is not simply required to make an appropriate additional contribution to the partnership, which the creditor can attach. Furthermore, the partner's liability is a primary one and not of a subsidiary character. In addition the partner's liability extends to his whole assets, and not merely to the value of his share of the partnership assets. It follows from the second sentence of paragraph 128 of the Code that the claims of third parties against the partners cannot be limited or excluded as the result of an agreement between them.

A creditor has the choice whether to proceed against the partnership or against one or more of the partners. It appears usual for proceedings to be taken both against the partnership and all the partners. If such process succeeds it may be followed by compulsory execution against the partnership property, and also against that of the individual partners.

If a claim is made against a partner in respect of a partnership liability he may defend himself against it in a number of ways, as is apparent from paragraph 129 of the
Commercial Code. It follows from, although it is not specifically provided in paragraph $129(1)$, that he can raise defences and make pleas which arise from the personal relationship between himself and the creditor. It also follows from paragraph 129(1) that he can invoke such defences and pleas that the partnership itself could raise against the claim. Furthermore, paragraph 129(2) provides that the partner may refuse to satisfy the creditor so long as the partnership has the right to contest the transaction underlying its obligation. Finally, paragraph 129(3) provides that the partner has the same right for so long as the creditor can satisfy the obligation by setting it off against a claim due to the partnership.

There is a considerable amount of academic controversy concerning the exact nature of what the personal liability of the partners for partnership obligations involves. In simple cases where a partner has to pay a partnership debt, this matter does not involve any difficulty. However, there are a number of different theories governing the nature of this liability, which have been applied in more complex cases. These theories are discussed at pages 85-6 of the work by Kübler and Assmann, already cited and also by Karsten Schmidt in the third edition of his major treatise, Gesellschaftrecht (note in particular pp 1418-22 thereof). According to the Erfüllungstheorie the partners are liable to fulfil the obligation incurred by the partnership. The application of this theory may lead to inequitable consequences where a partner who has himself done no wrong is asked to provide personal services which he is not qualified to furnish. This theory is sometimes replaced by the Haftungstheorie, according to which the content of the partner's obligation is his liability for the obligations of the partnership, which may be satisfied by monetary payments. Such satisfaction will not, however, be available where the creditor requires some action or abstention from the partnership, for example the provision of accounts or the restriction of competition.

In certain decisions the Supreme Court has determined the nature of the partners' obligations by looking not only at the interests of the creditor and the partners, but also at the partnership agreement (see BGHZ 23, 302; BGHZ 59, 64 and BGHZ ;73, 217) in order to determine whether the obligation undertaken by the partnership falls within the sphere of partnership activity carried out by the group of partners. If it does, the view has been taken that the interests of a creditor have primacy, and he may require its fulfilment from any of the partners. On the other hand, if the obligation falls within a private sphere, rather than that of the partnership, the view has been adopted in the first two Supreme Court decisions that have been cited that the interests of the creditor and the partners should be balanced against each other, in order to decide whether in the particular case a partner may be required to fulfil the obligation personally, or whether he is only liable to the creditor for its fulfilment by the partnership. The criteria set out in these cases appear somewhat imprecise. 
Paragraph 130 of the Commercial Code provides that a person joining an existing partnership is liable in the same way as the other partners under paragraphs 128 (which provides for unlimited liability) and 129 (for partnership liabilities incurred before he joined) irrespective of whether the name (Firma) of the partnership is changed. An agreement to the contrary has no effect as against third parties.

The personal liability of a partner does not cease with the dissolution of the partnership, or his withdrawal from it. Such liability is subject, however, to a limitation period of five years following its dissolution, according to paragraph 159(1). This period is reduced if the claim against the partnership has a shorter limitation period. By paragraph 159(2), the limitation period shall commence at the end of the day on which the dissolution of the partnership is registered in the Commercial Register. However, paragraph 159(3) stipulates that if the creditor's claim against the partnership becomes due after such registration the period shall commence on the date due. Paragraph 159(1) makes it clear that similar rules governing the limitation period are applicable to persons who were partners at the time of the dissolution.

According to paragraph 160(1) of the Commercial Code, if a partner withdraws from the partnership he remains liable for obligations incurred up to the time of such withdrawal if they become due prior to the end of five years thereafter, and claims resulting therefrom are asserted against him in a court of law. As far as public law obligations are concerned, an administrative order is equivalent to such assertion. The limitation period commences as of the end of the day on which the withdrawal is registered. By paragraph 106(2) if the partner has recognised the claim in writing, judicial assertion is unnecessary.

\section{ENDING AND CONTINUANCE OF A COMMERCIAL PARTNERSHIP}

The Aufösung (dissolution) of a commercial partnership is followed by its winding up (liquidation). The dissolution of a commercial partnership must, in accordance with paragraph 143(1) of the Commercial Code, be registered in the Commercial Register. The grounds for dissolution are set out in paragraph 131(1). These comprise expiration of the period for which the partnership was formed; a resolution of the partners; the commencement of insolvency proceedings against the property of the partnership; and a court order. By paragraph 131(2) of the Commercial Code, a commercial partnership in which no personally liable partner is a natural person is dissolved when a court order by which the commencement of insolvency proceedings is denied through lack of assets becomes final, and when such a partnership is struck off the Commercial Register owing to lack of assets in accordance with paragraph 141 of the Law Governing Non-Contentious Jurisdictions (this law applies to arbitration proceedings). Furthermore a partnership may be terminated by a partner. It follows from paragraph 132 of the Commercial Code that such termination (Kündigung) may only take place at the end of a business year; notice must be given of it at least six months prior to the end of the year. A partnership may, according to paragraph 135 of the Code, also be terminated by a private creditor who has unsuccessfully attempted execution on the property of a partner within the previous six months, by notice at least six months prior to the end of the business year.

As indicated above, a commercial partnership may be dissolved by a judicial decision. By paragraph 133(1), such dissolution may be pronounced for good reason on the application of a partner. The partnership agreement may contain provisions which facilitate this method of dissolution, for example by giving power to pronounce dissolution to an arbitration tribunal. The winding up of a commercial partnership is governed by the provision of paragraphs 145-58 of the Commercial Code. There are certain detailed provisions in paragraphs 131(3) No 6, 139 and 140(1) of the Commercial Code which are intended to avoid the dissolution (Aüflosung) and winding up (Liquidation) of commercial partnerships. The provisions of paragraphs 131(3) No 6,133 and 140(1) which relate to the exclusion of partners will be dealt with before the rather complex provisions of paragraph 139, which govern the continuation of a partnership with the heirs of a partner, are dealt with in outline.

Paragraph 131(3) No 6 together with paragraph 133(2) of the Commercial Code make it clear that where an important ground exists for the dissolution of a partnership by means of a court order, for example where a partner has intentionally, or in a grossly negligent manner violated a significant obligation in the partnership agreement, the other partners may resolve on his exclusion, rather than the dissolution of the partnership. It appears from paragraph 140(1) that such exclusion has to be confirmed by a court order. This text provides that where the personal circumstances are such as to give the other partners the right to demand the dissolution of the partnership, the court may, instead of ordering such dissolution, order the exclusion of the partner, provided that the other partners so request. The court action for exclusion shall not be prohibited by reason of the fact that only one partner will remain following such exclusion.

Detailed provisions concerning the continuation of a commercial partnership with the heirs of a partner are contained in paragraph 139 of the Code. Paragraph 139(1) stipulates that if a partnership agreement provides that on the death of a partner the partnership shall be continued with his heirs, each heir may make his continued participation in the partnership contingent on his being given the status of a limited partner (Kommanditist). He then maintains his share of the profits, and the portion of 
the deceased's contribution to the partnership, attributable to him is treated as his contribution to the limited partnership. This provision reflects the fact that all the heirs may not be competent to act as general partners, or indeed wish to do so. According to paragraph 139(2) if the remaining partners do not accept such a request by the heir then he may declare his immediate withdrawal from the partnership. Paragraph 139(3) provides that the designated rights may only be asserted by the heir within a period of three months following the time when he learns of the inheritance.

Dr Frank Wooldridge

\section{IALS Events}

All events take place at the Institute of Advanced Legal Studies except where otherwise indicated. Lectures and seminars free unless specified. CPD accreditation is provided with many events. For CPD and all other enquiries contact Belinda Crothers, Academic Programmes Manager, IALS, 17 Russell Square, London WC1B 5DR (tel: 0207862 5850; email: IALS.Events@sas.ac.uk). See also our website for further information (http://www.sas.ac.uk/events/list/ials_events).

Thursday, 12 November, 2.30pm

Half day seminar

Civil recoveries and criminal confiscation: $U K$ and EU interventions against fraud

Chair: SIMONE WHITE, European Anti-Fraud Office (OLAF); Visiting Fellow IALS Speakers: MICHAEL MAVRINAC, European Anti-Fraud Office (OLAF), "Recovering EU tax payers' money through the civil courts: a story worth telling;" ROD STONE, HMRC, "The development of civil interventions by HMRC to combat MTIC fraud: a UK operational perspective;" PHILIP MOBEDJI, Serious Fraud Office, "Civil Recovery/criminal confiscation and international requests for restraint and confiscation orders and similar requests to foreign jurisdiction from England”.

This afternoon seminar is free but those wishing to attend must book their place in advance.

Monday, 16 November, 12.45pm

Lunchtime tax seminar

\section{Recent ECJ cases update II}

Seminars are scheduled for Tuesdays with the exception of this one. All seminars will start at $12.45 \mathrm{pm}$ sharp.

Tuesday 17, November, 6pm

\section{PROFESSOR ELIZABETH COOKE}

Law Commissioner for England and Wales

Chair: LORD JUSTICE MUNBY, Chairman of the Law Commission for England and Wales.
Inheritance law in the 21 st century: the Law Commissioner's consultation on intestacy and family provision claims on death

Monday 23 November, $6.30 \mathrm{pm}$

\section{PROFESSOR JOHAN HENNING}

Dean of the Faculty of Law, University of the Free State, South Africa

The impact of the new South African Companies Act on more than a million close corporations: the beginning of the end?

Tuesday, 24 November $12.45 \mathrm{pm}$

Lunchtime tax seminar

Tax treaties and the ECJ

All seminars will start at $12.45 \mathrm{pm}$ sharp.

Thursday, 26 November, 6pm

PROFESSOR ANDREW HAYNES

University of Wolverhampton

Money laundering? Where are the authorities going now?

Tuesday, 1 December, 6pm

JAMES MICHAEL

Associate Senior Research Fellow, IALS; Editor, Privacy Laws \& Business International

Chair: RICHARD THOMAS, former Information Commissioner; Centre for Information Policy Leadership

Will privacy law in the 21 st century be European, American or international?

Friday, 4 December, 9.30am

One day seminar

Experiencing the law: objectifying children - policy making and human rights response

Speakers: NICK WIKELY, Southampton University; JEAN LA FONTAINE, LSE; LAURENCE LEE, Laurence 